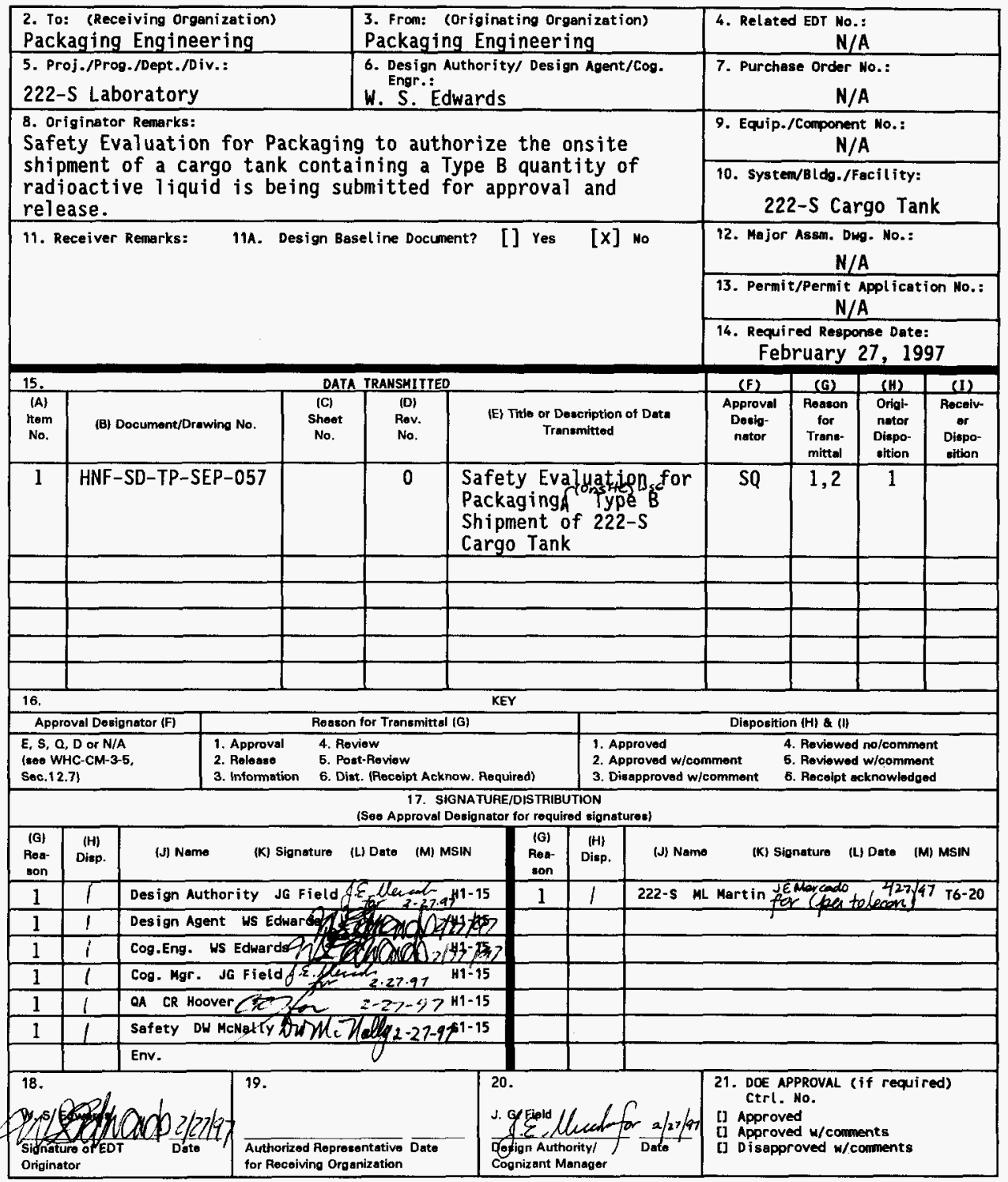

BD -7400-172-2 (05/96) GEF097 


\title{
Safety Evaluation for Packaging (Onsite) Type B Shipment of 222-S Cargo Tank
}

\author{
W. S. Edwards
}

Rust Federal Services Inc. Northwest Operations, Richland, WA 99352

U.S. Department of Energy Contract DE-AC06-96RL13200

\begin{tabular}{|c|c|c|}
\hline $\begin{array}{l}\text { EDT/ECN: } \\
\text { Org Code: } \\
\text { B\&R Code: }\end{array}$ & $\begin{array}{l}619554 \\
03 E 00 \\
\text { EW3130030 }\end{array}$ & $\begin{array}{l}\text { UC: } 513 \\
\text { Charge Code: } \\
\text { Tota1 Pages: }\end{array}$ \\
\hline
\end{tabular}

Key Words: transfer, 222-S Lab, 204-AR Transfer Station

Abstract: This safety evaluation for packaging (SEP) document was developed to provide safety evaluations necessary to approve the transfer of the 222-S Cargo Tank from the 222-S Lab to the 204-AR Transfer Station. The SEP demonstrates that the onsite transfer will provide an equivalent degree of safety as would be provided by a package meeting the U.S. Department of Transportation requirements. This fulfills the onsite transportation safety requirements implemented in WHC-CM-2-14, Hazardous Material Packaging and Shipping.

TRADEMARK D1SCLAIMER. Reference herein to any specific commercial product, process, or service by trade name, trademark, manufacturer, or otherwise, does not necessarily constitute or imply its endorsement, recommendation, or favoring by the United states Government or any agency thereof or its contractors or subcontractors.

Printed in the United States of America. To obtain copies of this document, contact: WHC/BCS Document Control Services, P.0. Box 1970, Mailstop H6-08, Richland wA 99352, Phone (509) 372-2420; Fax (509) 376-4989.
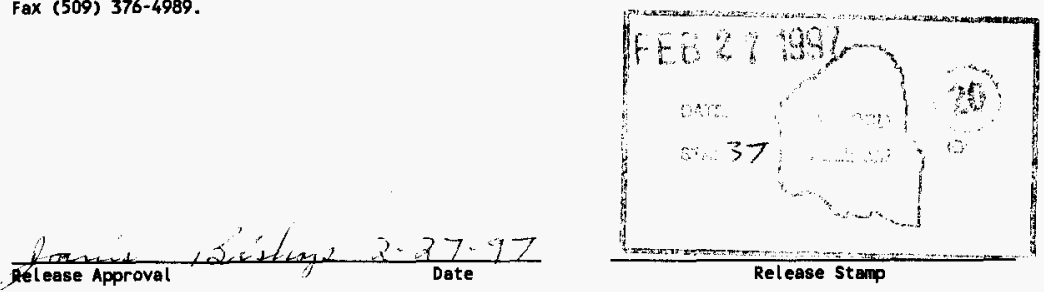

\section{Approved for Public Release}




$$
\text { HNF-SD-TP-SEP-057 Rev. } 0
$$

\section{CONTENTS}

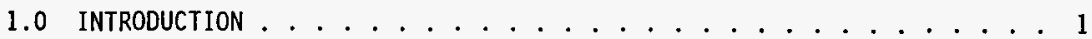

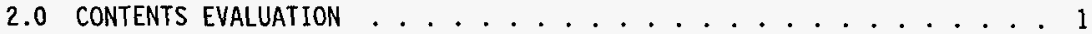

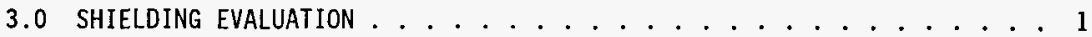

4.0 RADIOLOGICAL RISK EVALUATION ................ 2

4.1 RISK ACCEPTANCE CRITERIA . . . . . . . . . . . . . 2

4.2 DOSE CONSEQUENCE ANALYSIS . . . . . . . . . . . 3

4.3 PACKAGE FAILURE THRESHOLD ANALYSIS ............ 3

4.4 ACCIDENT FREQUENCY ASSESSMENT . . . . . . . . . . . 3

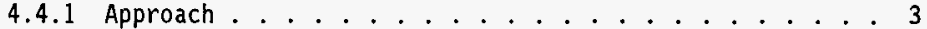

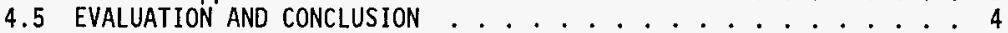

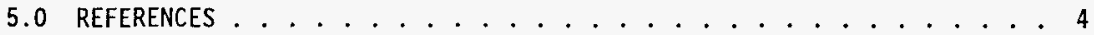

\section{LIST OF TABLES}

Table 2-1. Contents. ................. 6 Table 4-1. Risk Acceptance Criteria Limits. . . . . . . . . 2

Table 4-2. Summary .................. 4 
HNF-SD-TP-SEP-057 Rev. 0

\section{Safety Evaluation for Packaging (Onsite) \\ Type B Shipment of 222-S Cargo Tank}

\subsection{INTRODUCTION}

This is a one-time use Safety Evaluation for Packaging (Onsite) (SEP) for use of the 222-S Laboratory Cargo Tank (vehicle registration number H0-64-4275, serial number L1-10477) to transport radioactive liquid that exceeds the limits of the SEP for Transport of LSA-II Liquids in MC-312 Cargo Tanks (WHC-SD-TP-SEP-048 [Carlstrom 1996]). Except where noted in this SEP, this shipment meets all requirements of WHC-SD-TP-SEP-048. The 222-S Cargo Tank is a U.S. Department of Transportation (DOT) MC-312 specification cargo tank.

WHC-SD-TP-SEP-048 authorizes onsite shipment of 1ow specific activity (LSA-II) 1iquid in the 222-S Cargo Tank, with radiation dose rates less than $13 \mathrm{mrem} / \mathrm{h}$ at $2 \mathrm{~m}$ from the trailer. LSA-II material is defined in $49 \mathrm{CFR}$ 173.403 (1996) as material which is uniformly distributed and the specific activity is less than $10^{-5} \mathrm{~A}_{2} / \mathrm{g}$ for liquids.

\subsection{CONTENTS EVALUATION}

The package contents for this one-time SEP are provided in Figure 2-1. The contents have a specific activity of $7.446 \times 10^{-7} \mathrm{Cj} / \mathrm{g}$, which meets DOT limits for LSA-II materials. However, the contents do not meet the LSA-II definition of essentially uniformly distributed, since the radiation levels at the bottom are greater than the upper portions of the tank. The contents are fissile excepted per 49 CFR 173.453 (b) because the material contains less than $5 \mathrm{~g}$ of fissile material per liter, a mass of fissile radionuclides less than $500 \mathrm{~g}$, and a ratio of hydrogen atoms to fissile atoms greater than 5200 .

\subsection{SHIELDING EVALUATION}

The radiation level on the bottom of the tank exceeds the $13 \mathrm{mrem} / \mathrm{h}$ 1 imit of WHC-SD-TP-SEP-048. However, now that the tank is loaded, it would be very impractical to remove liquid form the cargo tank or install shielding on the cargo tank surface to reduce the dose rate to $13 \mathrm{mrem} / \mathrm{h}$. Performing those operations would increase exposure time to affected personnel and as low as reasonably achievable (ALARA) practices would not be followed. To prevent additional personnel exposure, a dose rate 1 imit of $100 \mathrm{mrem} / \mathrm{h}$ at $2 \mathrm{~m}$ is justified. 


$$
\text { HNF-SD-TP-SEP-057 Rev. } 0
$$

\subsection{RADIOLOGICAL. RISK EVALUATION}

This evaluation addresses a single shipment of the 222-S cargo tank from the 222-S Laboratory to the 204-AR Facility.

The assumptions for the radiological risk evaluation are the following:

- Highway shipment mode

- 1 shipment

- 10 miles

The 222-S Cargo Tank is designed to withstand normal transportation conditions. For accident environments, the cargo tank must meet onsite transportation safety requirements as outlined in WHC-CM-2-14 and Mercado (1994). The requisite safety is determined by a radiological risk evaluation, which uses risk acceptance criteria and Washington State truck accident

frequencies. For the evaluation, all accidents are binned to fall into four groups: impact, crush, puncture, and fire. Immersion as an accident scenario is ignored (H\&R 1995), because the transport route is not adjacent to water.

Risk acceptance criteria are outlined in Section 4.1. Dose consequence are discussed in Section 4.2. Failure thresholds are given in Section 4.3 and the analysis of accident release frequencies in Section 4.4. For this single cargo tank shipment, the accident frequencies provide the necessary input to evaluate risk acceptance.

\subsection{RISK ACCEPTANCE CRITERIA}

Graded dose limitations for probable, credible, and incredible accident frequencies ensure safety in radioactive material packaging and transportation (Mercado 1994). The dose limitations to the offsite and onsite individual for probable, credible, and incredible accident frequencies are shown in

Table 4-1.

Table 4-1. Risk Acceptance Criteria Limits.

\begin{tabular}{|l|l|l|l|}
\hline \multicolumn{1}{|c|}{ Description } & Annual frequency & \multicolumn{1}{|c|}{$\begin{array}{c}\text { Onsite } \\
\text { dose limit* } \\
\text { Sv (rem) }\end{array}$} & \multicolumn{1}{|c|}{$\begin{array}{c}\text { Offsite } \\
\text { dose limit* } \\
\text { Sv (rem) }\end{array}$} \\
\hline Incredible & $<10^{-7}$ & None & None \\
\hline Incredible & $10^{-7}$ to $<10^{-6}$ & None & $.25(25)$ \\
\hline Credible & $10^{-6}$ to $10^{-3}$ & $\begin{array}{l}.05 / .15 / .5 \\
(5 / 15 / 50)\end{array}$ & $\begin{array}{l}.005 / .015 / .05 \\
(.5 / 1.5 / 5)\end{array}$ \\
\hline Probable & $10^{-3}$ to 1 & $\begin{array}{l}.002 / .006 / .02 \\
(.2 / .6 / 2)\end{array}$ & $\begin{array}{l}.0001 / .0003 / .001 \\
(.01 / .03 / .1)\end{array}$ \\
\hline
\end{tabular}

*Effective dose equivalent/lens of eye/all other organs. 
The analysis of the 222-S Cargo Tank shipment initially focuses on determining whether the annual accident frequency for each major accident scenario is less than $10^{-7}$. If so, the necessity of determining the potential dose consequence resulting from the release of the payload is eliminated. If not, dose consequence calculations would be performed to allow comparisons to be made to risk acceptance criteria.

\subsection{DOSE CONSEQUENCE ANALYSIS}

The dose consequence of a failure of the cargo tank is not calculated for the purposes of the risk analysis because the magnitude of the annual accident frequencies is minimal, placing the probability of packaging failure well in the incredible range. This approach is justified by requiring that the accident scenarios evaluated encompass any event that would result in a loss of effectiveness of the packaging.

\subsection{PACKAGE FAILURE THRESHOLD ANALYSIS}

Failure thresholds were conservatively assumed to be minimal for the cargo tank. It was assumed that any accident event will result in packaging failure.

\subsection{ACCIDENT FREQUENCY ASSESSMENT}

\subsubsection{Approach}

The accident frequency assessment is based on the assumption that a single failure mode is appropriate for each of the different forces described as impact, puncture, crush, and fire. Packages on the Hanford Site do not encounter immersion accident environments. Package failure frequencies from different scenarios with similar consequences and the same type of force are evaluated to determine the four composite failure modes for this analysis.

The annual frequency (F) of a truck accident is the product of the annual number of trips, the number of miles per trip, and the accident rate per mile.

$$
F=1 \text { trip/year } x \text { miles/trip } x \text { accidents/mile }
$$

The truck accident rate is the Saricks and Kvitek (1994) value for the Washington State accident rate for secondary (rurai) state highways. This rate is $1.17 \times 10^{-7}$ accidents $/ \mathrm{mi}$. For the Hanford Site, this rate is reduced by a factor of 40 as recommended in Appendix B of H\&R (1995). This reduction factor takes credit for qualified, trained truck drivers (reduction factor of 10), shipment location north of the Wye Barricade (factor of 2), and the radioactive nature of the shipment (factor of 2 ).

The impact failure scenario is defined as the expected system velocity change resulting from the most severe impact experienced in a collision 
accident (Dennis et a1. 1978). The probability of occurrence of an impact or a puncture event is $0.8 \times \mathrm{F}$. The probability of occurrence of a crush event is 0.89 .

The conditional probability of occurrence of a fire is 0.0183 (from $H \& R$ [1995], Figure A.4).

\subsection{EVALUATION AND CONCLUSION}

Table 4-2 shows the risk evaluation summary. Each probability is then multiplied by $F$, the frequency, to arrive at an annual accident release frequency.

Table 4-2. Summary of Risk

Evaluation.

\begin{tabular}{|l|l|l|}
\hline $\begin{array}{c}\text { Failure } \\
\text { Mode }\end{array}$ & Criterion & \multicolumn{1}{c|}{$\begin{array}{c}\text { accident } \\
\text { frequency }\end{array}$} \\
\hline Impact & $<10^{-7}$ & $2.34 \times 10^{-8}$ \\
\hline Puncture & $<10^{-7}$ & $2.34 \times 10^{-8}$ \\
\hline Crush & $<10^{-7}$ & $2.60 \times 10^{-8}$ \\
\hline Fire & $<10^{-7}$ & $5.35 \times 10^{-10}$ \\
\hline Total & $<10^{-7}$ & $7.34 \times 10^{-8}$ \\
\hline
\end{tabular}

The annual accident release frequencies for 1 shipment per year of one cask meet the established criteria. Therefore, this single shipment of the 222-S Cargo Tank presents no unacceptable risks per WHC-CM-2-14 and Mercado (1994).

\subsection{REFERENCES}

49 CFR 173, 1996, "Shippers--General Requirements for Shipments and Packagings," Code of Federal Regulations, as amended.

Carlstrom, R. F., 1996, Safety Evaluation for Packaging (Onsite) Transport of LSA-II Liquids in MC-312 Cargo Tank, WHC-SD-TP-SEP-048, Westinghouse Hanford Company, Richland, Washington.

Dennis, A. W., et al., 1978, Severities of Transportation Accidents Involving Large Packages, SAND77-0001, Sandia National Laboratory, A1buquerque, New Mexico. 
Green, J. R., B. D. Flanagan, and H. W. Harris, Hanford Site Truck Accident Rate, 1990-1995, WHC-SD-TP-RPT-021, Rev. 0, Westinghouse Hanford Company, Rich1 and, Washington.

H\&R, 1995, Recommended Onsite Transportation Risk Management Methodology, 522-1, H\&R Technical Associates, Inc., Oak Ridge, Tennessee.

Mercado, J. E., 1994, Report on Equivalent Safety for Transportation and Packaging of Radioactive Materials, WHC-SD-TP-RPT-001, Rev. 0 , Westinghouse Hanford Company, Richland, Washington.

Saricks, C., and T. Kvitek, 1994, Longitudinal Review of State-Level Accident Statistics for Carriers of Interstate Freight, Center for Transportation Research, Argonne National Laboratory, Illinois. 
HNF-SD-TP-SEP-057 Rev. 0

Figure 2-1: Contents

\begin{tabular}{|c|c|c|c|c|c|c|c|c|c|}
\hline & Concen. & & & A2 & LSA-II & LSA-II & Grams & & \\
\hline NUCLIDE & (uCi/L) & $\mathbf{C i}$ & $\mathrm{Ci}$ /gram & Limit & (Ci/gram) & Fraction & Fissile & NUCLIDE & $\mathrm{uCi} / \mathrm{mL}$ \\
\hline $\mathrm{H}-3$ & 4.02E-01 & 4.48E-03 & 4.02E-10 & 1080 & $1.08 \mathrm{E}-02$ & 3.72E-08 & $\mathrm{N} / \mathrm{A}$ & $\mathrm{H}-3$ & 0.000402 \\
\hline Co-60 & $2.75 \mathrm{E}-01$ & $3.06 E-03$ & $2.75 \mathrm{E}-10$ & 10.8 & $1.08 \mathrm{E}-04$ & $2.55 \mathrm{E}-06$ & N/A & Co-60 & 0.000275 \\
\hline $\mathrm{C}-14$ & $2.28 \mathrm{E}-03$ & $2.54 E-05$ & $2.28 \mathrm{E}-12$ & 54.1 & $5.41 \mathrm{E}-04$ & $4.21 \mathrm{E}-09$ & N/A & C-14 & $2.28 \mathrm{E}-06$ \\
\hline Sr-90 & $1.14 \mathrm{E}+02$ & 1.27E+00 & 1.14E-07 & 2.7 & $2.70 \mathrm{E}-05$ & $4.22 \mathrm{E}-03$ & N/A & Sr-90 & 0.114 \\
\hline Y-90 & $1.14 E+02$ & $1.27 E+00$ & $1.14 \mathrm{E}-07$ & 5.41 & 5.41E-05 & $2.11 \mathrm{E}-03$ & N/A & $Y-90$ & 0.114 \\
\hline $1-129$ & 1.83E-02 & $2.04 \mathrm{E}-01$ & $1.83 \mathrm{E}-08$ & N/A & N/A & N/A & N/A & |-129 & 0.0000183 \\
\hline Tc-99 & $2.36 \mathrm{E}-01$ & $2.63 E-03$ & $2.36 \mathrm{E}-10$ & 24.3 & $2.43 \mathrm{E}-04$ & $9.71 \mathrm{E}-07$ & N/A & Tc-99 & 0.000236 \\
\hline Cs-137 & $4.96 \mathrm{E}+02$ & $5.52 E+00$ & 4.96E-07 & 13.5 & $1.35 \mathrm{E}-04$ & 3.67E-03 & N/A & Cs-137 & 0.496 \\
\hline $\mathrm{Pu}-238$ & $5.01 E-02$ & $5.58 E-04$ & 5.01E-11 & 0.00541 & $5.41 \mathrm{E}-08$ & $9.26 \mathrm{E}-04$ & $3.28 \mathrm{E}-05$ & Pu-238 & 0.0000501 \\
\hline Pu-239/40 & $2.95 E-01$ & $3.28 \mathrm{E}-03$ & $2.95 \mathrm{E}-10$ & 0.00541 & $5.41 \mathrm{E}-08$ & $5.45 \mathrm{E}-03$ & \begin{tabular}{|l|}
$5.30 \mathrm{E}-02$ \\
\end{tabular} & $\mathrm{Pu}-239 / 40$ & 0.000295 \\
\hline$A m-241$ & $1.58 \mathrm{E}+00$ & $1.76 \mathrm{E}-02$ & $1.58 \mathrm{E}-09$ & 0.00541 & $5.41 \mathrm{E}-08$ & $2.92 \mathrm{E}-02$ & N/A & Am-241 & 0.00158 \\
\hline SUM & & $8.29 E+00$ & & & & $4.56 \mathrm{E}-02$ & $5.30 \mathrm{E}-02$ & & \\
\hline & & & & & & & & & \\
\hline \multicolumn{2}{|l|}{ Assume $1 \mathrm{~g} / \mathrm{ml}$} & & & Total $\mathrm{Ci}$ & $=$ & $8.29 E+00$ & & & \\
\hline \multirow[t]{5}{*}{ Volume } & $=$ & $1.1133 E+04$ & Liters & Total grams & & & & & \\
\hline & & $1.1133 E+07$ & grams & Fissile & $=$ & $5.30 \mathrm{E}-02$ & & & \\
\hline & & & & & & & & & \\
\hline & & (2941 Gallons) & $+800 \mathrm{aa}$ & prax) & of treat & ment & fush & ter. & \\
\hline & & & & & & & \multicolumn{2}{|c|}{$4 \mathrm{~g} \mu 2=27 / 97$} & \\
\hline Spec. Activity & & $7.44 E-07$ & $\mathrm{Ci} / \mathrm{I}$ & & & & & & \\
\hline & & & & & & & & & \\
\hline Fissile Conc. & & 4.76E-09 & $g / l$ & & & & & & \\
\hline & & & & & & & & & \\
\hline & & & & & & & & & \\
\hline & & & & & & & & & \\
\hline & & & & & & & & & \\
\hline & & & & & & & & & \\
\hline & & & & & & & & & \\
\hline & & & & & & & & & \\
\hline & & & & & & & & & \\
\hline & & & & & & & & & \\
\hline
\end{tabular}




\begin{tabular}{|c|c|c|c|c|c|}
\hline \multicolumn{6}{|c|}{ DISTRIBUTION SHEET } \\
\hline To & \multirow{2}{*}{\multicolumn{3}{|c|}{$\begin{array}{l}\text { From } \\
\text { Packaging Engineering }\end{array}$}} & \multicolumn{2}{|l|}{ Page 1 of 1} \\
\hline Distribution & & & & \multicolumn{2}{|c|}{ Date Feb. 27, 1997} \\
\hline \multicolumn{4}{|l|}{ Project Title/Work Order } & \multicolumn{2}{|c|}{ EDT No. 619554} \\
\hline \multicolumn{4}{|c|}{$\begin{array}{l}\text { Safety Evaluation for Packaging (Onsite) Type B Shipment of } \\
222-S \text { Cargo Tank (HNF-SD-TP-SEP-057, Rev. 0) }\end{array}$} & \multicolumn{2}{|c|}{ ECN No. $N / A$} \\
\hline Name & MSIN & $\begin{array}{c}\text { Text } \\
\text { With All } \\
\text { Attach. }\end{array}$ & Text Only & $\begin{array}{l}\text { Attach./ } \\
\text { Appendix } \\
\text { Only }\end{array}$ & $\begin{array}{l}\text { EDT/ECN } \\
\text { Only }\end{array}$ \\
\hline $\begin{array}{l}\text { R. L. Clawson } \\
\text { W. S. Edwards } \\
\text { J. G. Field } \\
\text { C. R. Hoover } \\
\text { M. L. Martin } \\
\text { D. W. McNally } \\
\text { Central Files }\end{array}$ & $\begin{array}{l}H 1-15 \\
H 1-15 \\
H 1-15 \\
H 1-15 \\
T 6-20 \\
\text { G1-15 } \\
\text { A3-88 }\end{array}$ & $\begin{array}{l}x \\
x \\
x \\
x \\
x \\
x \\
x\end{array}$ & & & \\
\hline HNF-SD-TP-SEP-057 File & $\mathrm{H} 1-15$ & $x$ & & & \\
\hline
\end{tabular}

